\title{
Slavery, Emancipation, and Reconstruction in the Midwest: A Review Essay
}

\author{
LESLIE SCHWALM
}

Slavery in the Upper Mississippi Valley, 1787-1865: A History of Human Bondage in Illinois, Iowa, Minnesota and Wisconsin, by Christopher P. Lehman. Jefferson, NC: McFarland \& Co., Inc., 2011. vi, 228 pp. Illustrations, notes, bibliography, index. $\$ 45.00$ paper.

"We Will Be Satisfied with Nothing Less": The African American Struggle for Equal Rights in the North during Reconstruction, by Hugh Davis. Ithaca: Cornell University Press, 2011. xvii, 232 pp. Notes, bibliography, index. $\$ 45.00$ cloth.

NO GEOGRAPHIC, political, or territorial boundary contained the practice of American slavery to the South. Owning, hiring, inheriting, and trading in enslaved African and African American people was a national phenomenon from slavery's earliest beginnings to its final end, despite popular misunderstandings and convenient stereotypes of the "peculiar institution" as a uniquely southern development. National, too, were the consequences of slavery's wartime demise and the postwar conflict over the citizenship and civil rights that accompany freedom, with critical debates and battles occurring in places like Keokuk, San Francisco, and Philadelphia. This overlooked national story of slavery, emancipation, and Reconstruction has drawn increasing attention from scholars, and two recent books are helpful in elaborating on the Midwest's particular place in this history.

THE ANNALS OF IOWA 71 (Fall 2012). (C) The State Historical Society of Iowa, 2012. 
Christopher P. Lehman's exploration of slavery in the upper Midwest and Hugh Davis's study of the Reconstruction-era civil rights struggle in the North are recent additions to this new wave, and each shows how and why Iowa played a role in these poorly understood national histories.

Lehman, a scholar of twentieth-century popular culture and race, has gathered considerable evidence of upper midwestern slavery, organizing his book into chapter-by-chapter treatments of what he argues are slavery's unique characteristics in each upper midwestern state-indentured servitude in Illinois, lead mining and the presence of slaves in U.S. army posts in Wisconsin, the migration of southern slaveholders with enslaved people to Iowa, and the prevalence of hoteliers (serving southern clientele) among Minnesota's slaveowners. This is a traditional, top-down account (from the perspective of slaveowners, legislators, and territorial and state officials) based largely on print sources (published memoirs; local, county, and state histories; family histories; biographical dictionaries; and newspapers). This work is not rooted in unpublished archival sources nor does it offer a critical engagement with the historian's craft; instead, it serves largely as a collation of the extensive print references to midwestern slaveowners and, less frequently, to the people they held as slaves. Surprisingly, Lehman does not use such rich archival sources as the Illinois servitude and emancipation records or the hundreds of freedom suits made by enslaved people (many having been held in the upper Midwest) in the St. Louis circuit court, both readily accessible online. Nor does the work engage with the important and exciting scholarship on slavery, especially the most relevant studies of slavery beyond the plantation that might have led the author, for example, to more coherent observations about the similarities between midwestern and some southern economies of slavery (including the prevalence of slave hiring and the centrality of investments and trade in slave property to a wide range of economic practices). With these shortcomings in mind, the volume is most valuable as an introductory overview. Readers looking for a critical engagement with midwestern slavery, for guidance on how midwestern practices compared to other regional practices (such as the tolerance of "sojourning" slaveowners), or for 
revelations about the experience of enslaved people (their culture, the communities they formed in Wisconsin's lead mining district or in the U.S. army posts that dotted the region, the many extralegal forms that enslavement took in Iowa) will be disappointed, but teachers and general readers will find useful information gathered into this accessible account.

Hugh Davis, a scholar of northern antislavery and its religious leaders, offers an ambitious and important scholarly treatment of northern Reconstruction. Reconstruction has been understood as though the former Confederate states alone battled with the ending of slavery, the enfranchisement of black men, and the struggle over civil rights legislation. Davis offers a substantial correction to this misconception. The most sweeping study of northern civil rights activism in several decades, Davis's work relies on unpublished family papers, government documents, convention proceedings, petitions, newspapers, and state and local records to show the scope of organized and individual efforts of African American men and women to gain equal citizenship and civil rights in the North. From Philadelphia and Boston to Cleveland, Detroit, Cairo, and Keokuk, Davis traces the efforts of local communities, state conventions, and regional and national organizations to achieve political and civil equality in the postwar era. Although these movements necessarily varied (as did the state laws and local practices they battled), Davis finds that activists across the North shared common ground in their emphasis on two key issues above all others: black male enfranchisement and equal access to public schools.

The story of northern white resistance to black enfranchisement has appeared in other studies, but Davis interweaves this better-known story with a new and careful consideration of how northern blacks built a social movement, including careful attention to diverging goals (universal or impartial suffrage?), contested leadership, and ideological conflict, but also to the rich array of strategies that men and women pursued (from meetings with presidents to confronting local registrars with their demands to be enrolled as voters). By documenting the difficult struggle for enfranchisement, Davis helps to clarify that citizenship, no less than black freedom, came through the sacrifices and efforts of African Americans-not as a gift from egali- 
tarian white benefactors. Davis also carefully notes the consequences of enfranchisement; as a small minority in most northern states, African American voters were frequently disappointed by their inability to affect public policy and by the Republican Party's unwillingness to endorse black candidates for office.

Davis also traces the struggle for equal access to public schools, carefully contextualizing the many forms that exclusion and segregation took in the postwar North. African Americans faced difficult challenges, as revealed in the story of the desegregation efforts in Keokuk. There, black Iowans had responded to the segregation of grammar schools by building (with public funds) the state's largest and most advanced black school, staffed by prominent educators, male and female. In their decision to challenge the injustice of segregation (and the exclusion of black pupils from high school), African Americans knew that their victory would result in the loss of their school and the loss of teaching jobs (as no white board of education in Iowa would deign to employ black teachers for white students). Yet the men and women who taught black children in Keokuk were at the forefront of the struggle in the 1870s, as black Iowans soughtand sacrificed a great deal-for the full range of educational opportunities that their children deserved.

Despite the passage of the Fourteenth and Fifteenth amendments to the U.S. Constitution and the Civil Rights Bill of 1875, black citizenship and civil rights remained tentative in many northern communities well into the twentieth century. Davis notes that the burden of civil rights enforcement typically fell on black litigants; that the right to vote did not often translate into officeholding, patronage appointments, or legislative influence; and that the Republican Party's retreat from Reconstruction was not only a retreat from enforcement in the South, but in the North as well. Changes in the law did not result in social or cultural change; black freedom did not achieve racial equality in the North. But what Davis documents is the willingness and determination of African Americans to pursue expanding opportunities, especially for their children, even in the face of continued discrimination and segregation. Iowa was a part of that story, and this book allows us to place the black teachers of Keokuk alongside their fellow activists in Ohio and Nevada 
and appreciate the commitment of African Americans to a nation that failed them so easily and persistently.

Readers will find in Davis's footnotes a rich bibliography and occasional engagements with scholarly debates. These reveal some of the critical scholarly decisions Davis made about how to frame his subject. Different decisions might have yielded a more complex understanding of the meaning of citizenship among African Americans. Had Davis decided to pay closer attention to civil rights case law, he would have discovered the prominent efforts of women to challenge practices of exclusion and segregation in public transportation, accommodations, and schools. And had he delved more deeply into black cultural institutions such as the churches, fraternal orders, and literary associations that were so important to black life in the North, he would have found rich evidence of how northern black men and women agreed-and disagreed-about the rights of women relative to those of men. African American women were not only responding to the racism of white women as they sought fuller citizenship; as historian Martha Jones has shown, African Americans had pondered and grappled with the question of women's public role and authority for decades before the Civil War. The wartime struggle for the right of black men to enlist also gave new, more powerful valence to the meaning of manhood for black Americans. Gender was a salient feature of African American rhetoric about rights and citizenship in the postwar North. Davis's study would have been richer had he paid greater attention to its impact on the goals and strategies of the men and women whose activism he brings to light.

Together, Lehman and Davis offer an important corrective to those who assume that the history of race is not a centrally midwestern or Iowa story. 